\title{
Alpha-Linolenic Acid: It Contribute Regulation of Fertilization Capacity and Subsequent Development by Promoting of Cumulus Expansion during Maturation
}

\author{
Ji-Eun Lee ${ }^{1}$, Yong Hwangbo ${ }^{1}$, Hee-Tae Cheong ${ }^{2}$, Boo-Keun Yang ${ }^{1}$, and ${ }^{\dagger}$ Choon-Keun Park ${ }^{1}$ \\ ${ }^{1}$ College of Animal Life Sciences, Kangwon National University, Chunchoen 24341, Korea \\ ${ }^{2}$ College of Veterinary Medicine, Kangwon National University, Chunchoen 24341, Korea
}

\begin{abstract}
The objective of this study was to evaluate the effects of alpha-linolenic acid (ALA) during in vitro maturation (IVM) on cumulus expansion, nuclear maturation, fertilization capacity and subsequent development in porcine oocytes. The oocytes were incubated with $0,25,50$, and $100 \mu \mathrm{M}$ ALA. Cumulus expansion was measured at $22 \mathrm{~h}$, and gene expresison and nuclear maturation were analyzed at $44 \mathrm{~h}$ after maturation. Then, mature oocytes with ALA were inseminated, and fertilization parameters and embryo development were evaluated. In results, both of cumulus expansion and nuclear maturation were increased in $50 \mu \mathrm{M}$ ALA groups compared to control groups $(p<0.05)$. However, expression of gap junction protein alpha 1 (GJA1, cumulus expansion-related gene), delta-6 desaturase (FADS1, fatty acid metabolism-related gene), and delta-5 desaturase (FADS2) mRNA in cumulus cells were reduced by $50 \mu \mathrm{M}$ ALA treatment $(p<0.05)$. Cleavage rate was enhanced in 25 and $50 \mu \mathrm{M}$ ALA groups $(p<0.05$ ), especially, treatment of $50 \mu \mathrm{M}$ ALA promoted early embryo develop to 4 and 8 cell stages $(p<0.05)$. However, blastocyst formation and number of cells in blastocyst were not differ in 25 and $50 \mu \mathrm{M}$ ALA groups. Our findings show that ALA treatment during maturation could improve nuclear maturation, fertilization, and early embryo development through enhancing of cumulus expansion, however, fatty acid metabolism- and cumulus expansion-related genes were down-regulated. Therefore, addition of ALA during IVM of oocytes could improve fertilization and developmental competence, and further studies regarding with the mechanism of ALA metabolism are needed.
\end{abstract}

Key words : Alpha-linolenic acid, In vitro maturation, Cumulus expansion, Monospermy, Embryo development, Pigs

\section{INTRODUCTION}

Because pigs have anatomical and physiological similarities with human, they are considered as useful animal model for xenotransplantation, stem cell research model, and human disease model. Therefore, establishment and improvement of optimal in vitro production (IVP) system are very important for various researches (Sovernigo et al., 2017), however, quality of in vitro-produced embryos is still lower than in vivo (Gilchrist, 2010). To improve low efficiency of IVP system, a variety of substances, such as vitamin, antioxidants, and hormoens, have been supplied to medium for IVP of oocytes (Kwak et al., 2012; Tareq et al.,2012; Li et al., 2017).

Polyspermy is a major obstacle for IVP of porcine embryos and frequency of polyspermic fertilization was higher in in vitro than in vivo (Reis, 1993; Hoodbhoy and Talbot, 1994; Li et al., 2003). During the maturation process of

\footnotetext{
Manuscript received October 5, 2018, Received in revised form October 20, 2018, Accepted November 10, 2018

${ }_{\dagger}$ Corresponding Author: Choon-Keun Park, College of Animal Life Sciences, Kangwon National University, Chuncheon 24341, Korea. Tel: +82-33-2508627, E-mail: parkck@kangwon.ac.kr

This is an Open Access article distributed under the terms of the Creative Commons Attribution Non-Commercial License (http:// creative-commons.org/licenses/by-nc/3.0) which permits unrestricted non-commercial use, distribution, and reproduction in any medium, provided the original work is properly cited.
} 
oocytes in vitro, nuclear maturation of porcine oocytes was faster than cytoplasmic maturation and these mismatch between cytoplasmic and nuclear maturation was caused incomplete maturation status of oocytes and inducing of polyspermy, resulting a lower rate of in vitro development after fertilization (Wang et al., 1997; Elahi et al., 2016). Therefore, regulation of both cytoplasm and nuclear maturation is very important to prevent polyspermy.

Recently, many studies have been conducted to determine whether dietary intake of polyunsaturated fatty acid (PUFA) in cattle could improve reproductive performance. Childs et al. (2008) reproted that PUFAs supplement by diet in cattle increased proportion of PUFAs in follicular fluids and Fouladi-Nashta et al. (2007) reproted that developemental competence of oocytes and quality of blastocyst were enhanced by dietary PUFAs in cows. These reseaches suggested that supplementation of fatty acids (FAs) could improve quality and developmental potential of mammalian oocytes.

Alpha-linolenic acid (ALA), is one of PUFAs, is present in follicles, oocytes, and spermatozoa in mammals (Homa and Brown, 1992). Marei et al. (2009) reported that addition of ALA in maturation medium for bovine oocytes enhanced clevage rate, blastocyst formation rate, and embryo quality. Our previous study also showed that the treatment of $50 \mu \mathrm{M}$ ALA during in vitro maturation (IVM) of porcine oocytes significantly increased the metaphase-II reached oocytes, and cleavage rate and numbe of cells in blastocysts were increased by ALA treatment during in vitro culture (IVC) (Lee et al., 2017a). Therefore, we hypothesized that addtion of ALA during maturation of mammalian oocytes have benefical effect as an energy sourse and this study was conducted to evaluate effect of ALA during IVM on improvement of fertilization and developmental competence of porcine oocytes via cumulus expansion. Futhermore, the expression of FA metabolism- and cumulus expansion-related genes were measured.

\section{MATERIALS AND METHODS}

\section{Oocytes collection and in vitro maturation (IVM)}

All procedures that involved the use of animals were approved by the Kangwon National University Institutional Animal Care and Use Committee (KIACUC-090139). Ovaries were collected from local slaughterhouse and transferred to the laboratory in $0.9 \%(\mathrm{w} / \mathrm{v})$ sterilized saline within $2 \mathrm{~h}$. The cumulus-oocyte complexes (COCs) were aspirated from antral follicles (3-6 $\mathrm{mm}$ diameter) using 18-gauge needle with $10 \mathrm{cc}$ syringe. After aspiration, COCs with compact cumulus layer and homogeneous cytoplasm were selected and incubated in medium-199 (Invitrogen, MA, USA) containing 10\% (v/v) porcine follicular fluid $(\mathrm{pFF}), 10 \mathrm{IU} / \mathrm{mL}$ human chorionic gonadotropin (hCG; Intervet), $10 \mu \mathrm{g} / \mathrm{mL}$ luteinizing hormone (LH; Sigma-aldrich, St. Louis, MO, USA), $0.5 \mu \mathrm{g} / \mathrm{mL}$ follicle stimulating hormone (FSH; Sigma-Aldrich) and 10 $\mathrm{ng} / \mathrm{mL}$ epidermal growth factor (EGF; Sigma-aldrich) with $0,25,50$, and $100 \mu \mathrm{M}$ ALA at $38.5^{\circ} \mathrm{C}$ in $5 \% \mathrm{CO}_{2}$ for 20 $22 \mathrm{~h}$. Then, they were subsequently incubated in hormonefree maturation medium for 20-22 h.

\section{Measurement of cumulus expansion}

To assess effect of ALA treatment on cumulus expansion, COCs were incubated with different concentration of ALA and area of COCs was observed using inverted microscope at $22 \mathrm{~h}$ after maturation. Then, cumulus area from 50 COCs in each treatment groups was measured using Image J software (Version 1.46; National Institutes of Health, Bethesda, MD, USA) and was normalized to control group.

\section{Evaluation of nuclear maturation}

Aceto-orcein stain method was used to evaluate nuclear maturation stage of porcine oocytes. The oocytes were incubated with $50 \mu \mathrm{M}$ ALA during IVM. The cumulus cells were removed by gentle pipetting with $0.1 \%$ hyaluronidase and denuded oocytes were fixed in fixation solu- 
tion (acetic acid : ethanol; $1: 3 ; \mathrm{v} / \mathrm{v}$ ) at room temperature (RT) for $48 \mathrm{~h}$ and nuclear in oocytes was stained by $1 \%$ (w/v) aceto-orecein for $7 \mathrm{~min}$. The morphology of nuclear was observed under light microscope. The oocytes at germinal vesicle $(\mathrm{GV})$, germinal vesicle breakdown (GVBD), metaphase I (MI), anaphase (AI) and telophase I (TI) phase were decided as immature oocyte and metaphase II (MII) stage were classified as mature oocytes.

\section{In vitro fertilization (IVF)}

The cumulus cells surrounding COCs mature with different concentration of ALA were removed by gentle pipetting with $0.1 \%$ hyaluronidase. And 15-20 oocytes were placed in $50 \mu \mathrm{l}$ drop of modified tris-buffered medium (mTBM) containing $0.2 \%(\mathrm{w} / \mathrm{v})$ bovine serum albumin (BSA; Sigma-Aldrich). Boar semen were washed twice using modena B and were diluted with mTBM containing $0.4 \%(\mathrm{w} / \mathrm{v})$ BSA and $0.39 \mathrm{mg} / \mathrm{mL}$ caffeine (Sigma-Aldrich) at a final concentration of $6 \times 10^{5}$ spermatozoa $/ \mathrm{mL}$. Then, $50 \mu \mathrm{L}$ aliquots of sperm were added and co-incubated with denuded oocytes for 18-20 h.

\section{Evaluation of sperm penetration}

To evaluate sperm penetration into oocytes, aceto-orcein stain was used. The spermatozoa surrounding putative zygotes were removed and zygotes were fixed in fixation solution for $48 \mathrm{~h}$. Then, they were stained by $1 \%$ acetoorcein solution for $7 \mathrm{~min}$ and observed under light microscope. We evaluated IVF parameter by number of pronuclear formation: penetrated zygote (more than 2 pronuclear), monospermic fertilization (monospermy; with 2 pronuclear), and IVF efficiency (rate of monospermic zygotes to the number of penetrated oocytes).

\section{In vitro culture (IVC)}

After fertilization, spermatozoa surrounding zygotes were completely removed by gentle pipetting. Twenty fertilized zygotes were transferred to $100 \mu \mathrm{L}$ drop of porcine zygote medium-3 (PZM-3) containing 0.3\% (w/v) BSA (Sigma-Aldrich) and were cultured at $38.5^{\circ} \mathrm{C}$ in $5 \% \mathrm{CO}_{2}$ for $48 \mathrm{~h}$. Then, 50 embryos were transferred to $650 \mu \mathrm{L}$ of PZM-3 in 4-well culture plate and subsequently cultured for $120 \mathrm{~h}$. The cleavage rate and blastocyst formation were evaluated at 48 and 168 h post-insemination, respectively.

\section{Cell number in blastocyst}

Blastocysts at 7 day after insemination were used to measure cell number in blastocyst. Embryos at blastocyst stage were fixed in $4 \%(\mathrm{v} / \mathrm{v})$ formaldehyde solution at RT for $3 \mathrm{~min}$ and were stained by $1 \mu \mathrm{g} / \mathrm{mLbisbenzimide} \mathrm{H}$ 33342 trihydrochloride (Hoechst 33342; Sigma-Aldrich) at RT for $30 \mathrm{~min}$ in dark room. Stained nuclear in blastocysts were observed under fluorescent microscope using UV filter $(400 \mathrm{~nm})$.

\section{Quantitative real time PCR}

Total RNA extraction from cumulus cells, cultured with ALA for $44 \mathrm{~h}$, was performed using trizol reagent (Takara, Japan) and cDNA was synthesized using Prime Script 1st strand cDNA Synthesis Kit (Takara) according to the manual. In brief, $1 \mu \mathrm{g}$ of total RNA were incubated with 5 $\mu \mathrm{M}$ Oligo dT primer and $1 \mathrm{mM}$ dNTP mixture at $65^{\circ} \mathrm{C}$ for $5 \mathrm{~min}$, and it was immediately cooled on ice after incubation. Then, RNA was mixed with 1 units/ $\mu 1$ RNase inhibitor and $10 \mathrm{unit} / \mu \mathrm{L}$ RTase and mixture was reacted to synthesize cDNA at $42^{\circ} \mathrm{C}$ for $1 \mathrm{~h}$. Synthesized cDNA was quantified using NanoDrop 2000 (Thermo Scientific Nanodrop, Wilmington, DE, USA) and was diluted concentration at $50 \mathrm{ng} / \mu \mathrm{L}$ for real time PCR. All of primers for FAs metabolism- (delta-6 desaturase, FADS1; delta-5 desaturase, $F A D S 2$, peroxisome proliferator-activated receptor-alpha, $P P A R \alpha)$ and cumulus expansion-related genes (pentraxin, PTX3; gap junction protein 1, GJA1; prostaglandin-endoperoxide synthase 2, PTGS2) was designed using Primer3 on-line software (Table 1). Thunderbird SYBR qPCR mix (Toyobo, Japan) was used for real-time PCR and cDNA 
Table 1. Primer sequences and condition using real-time PCR

\begin{tabular}{clccc}
\hline \hline \multirow{2}{*}{ Gene } & \multicolumn{1}{c}{ Primer sequence $\left(5^{\prime} \rightarrow 3^{\prime}\right)$} & Product size $(\mathrm{bp})$ & Annealing temp. & Accession number \\
\hline \multirow{2}{*}{ FADS1 } & $\begin{array}{l}\text { F: CGTGATTGACCGGAAGGTGT } \\
\text { R: CCACAAAGGGATCCGTAGCA }\end{array}$ & 110 & $60^{\circ} \mathrm{C}$ & NM_001113041.1 \\
\hline FADS2 & $\begin{array}{l}\text { F: CCGGTTGAGTACGGCAAGAA } \\
\text { R: CCAGGACACCGTAGAAAGGG }\end{array}$ & 217 & $60^{\circ} \mathrm{C}$ & NM_001171750.1 \\
\hline PPAR 2 & $\begin{array}{l}\text { F: GTTGCAAGGGCTTCTTTCGG } \\
\text { R: CCGAGAGGCACTTGTGGAAA }\end{array}$ & 129 & $60^{\circ} \mathrm{C}$ & NM_001044526 \\
\hline PTX3 & $\begin{array}{l}\text { F: GCCAGCAGGTTGTGAAACAG } \\
\text { R: GGCTTTGACCCAAATGCAGG }\end{array}$ & 121 & $60^{\circ} \mathrm{C}$ & NM_001244783 \\
\hline \multirow{2}{*}{ FJA1 } & $\begin{array}{l}\text { F: CTCTGAGGCGTGCCTACTTC } \\
\text { R: CTAAGGCACTCCAGTCACCC }\end{array}$ & 77 & $60^{\circ} \mathrm{C}$ & NM_001244212.1 \\
\hline PTGS2 & $\begin{array}{l}\text { F: ATCCTCCGACAGCCAAAGAC } \\
\text { R: AGCCGTTCATCGTCCCATTC }\end{array}$ & 199 & $60^{\circ} \mathrm{C}$ & NM_214321 \\
\hline GAPDH & $\begin{array}{l}\text { F: CATGGTTCACGCCCATCACA } \\
\text { R: TCCCGCCAACATCAAATGGG }\end{array}$ & 170 & $60^{\circ} \mathrm{C}$ & NM_001206359 \\
\hline
\end{tabular}

FADS1, delta-6 desaturase; FADS2, delta-5desaturase; PPAR $\alpha$, peroxisome proliferator-activated receptor-alpha; PTX3, pentraxin; GJA1, gap junction protein alpha 1; $P T G S 2$, prostaglandin-endoperoxide synthase 2; GAPDH, glyceraldehyde3-phosphate dehydrogenase

amplification was performed following conditions: denaturation; $95^{\circ} \mathrm{C}$ for $15 \mathrm{sec}$, annealing; $60^{\circ} \mathrm{C}$ for $30 \mathrm{sec}$, extension; $72^{\circ} \mathrm{C}$ for $30 \mathrm{sec}$. Relative expression level of genes were normalized to glyceraldehyde-3-phosphate dehydrogenase $(G A P D H)$ and analyze by $2^{-\Delta \Delta C t}$ method.

\section{Experimental designs}

1) Experiment 1: Effect of ALA during IVM on cell expansion, nuclear maturation, and gene expression of cumulus cells and oocytes

To evaluate effect of different concentration of ALA on cumulus cell expansion of COCs, porcine COCs were incubated in IVM medium with different concentration of $\operatorname{ALA}(0,25,50$, and $100 \mu \mathrm{M})$ during first $22 \mathrm{~h}$ of IVM and cumulus cell expansion was measured using Image J. Based on result in cumulus cell expansion, nuclear maturation of oocytes and gene expression in cumulus cells that was incubated with $50 \mu \mathrm{M}$ ALA at $44 \mathrm{~h}$ after maturation.

2) Experiment 2: Change of fertility in porcine oocytes mature with ALA

To confirm changes of fertility of oocytes by ALA, oocytes were incubated with ALA $(0,25,50$, and $100 \mu \mathrm{M})$ and were ferilized for 18-20 h. Then, sperm penetration and pronuclear formation were evaluated by aceto-orcein stain method.

3) Experiment 3: Effect of ALA during IVM on developmental competence of porcine oocytes

Experiment 3 was conducted to investigate whether treatment of $\operatorname{ALA}(0,25,50$, and $100 \mu \mathrm{M})$ during maturation influence to development competence of oocytes. Therefore, cleavage rate and blastocyst formation were evaluated at 48 and $168 \mathrm{~h}$ after insemination, respectively. Especially, rates of embryos at 2, 4, and 8 cells stages were 
compare to investigate effect of ALA on early embryo development in pigs. As one of embryo quality parameters, total cell number in blastocyst at day 7 post-insemination was observed.

\section{Statistical analysis}

All numerical data representing each parameter were analyzed using the Statistical Analysis System Software (SAS version 9.4). Data are presented means \pm SEM, and comparisons among treatment groups were conducted by Duncan's multiple range tests (cumulus expansion, sperm penetration, and embryo development) and $t$-test (nuclear maturation and real time PCR) using a generalized linear model (GLM) in the SAS package. A value of $p<0.05$ was considered to indicate a statistically significant difference.

\section{RESULTS}

1. Effect of ALA during IVM on cell expansion, nuclear maturation, and gene expression of cumulus cells and oocytes

Treatment of $50 \mu \mathrm{M}$ ALA during first $22 \mathrm{~h}$ of IVM increased cumulus expansion compared to control and other treatment groups (Fig. 1; $p<0.05$ ) and ratio of meture oocytes at $44 \mathrm{~h}$ after IVM was higher in $50 \mu \mathrm{M}$ ALA treatment group than control group (Fig. $2 ; p<0.05$ ). Although cumulus expansion and nuclear maturation were enhanced, expression of GJA1, FADS1, and FADS2 mRNA in cumulus cells were reduced by treatment of $50 \mu \mathrm{M}$ ALA (Fig. 3; $p<0.05)$.

\section{Change of fertilization in porcine oocytes mature} with ALA

Change of IVF parameters by ALA during IVM was showed in Table 2. Sperm penetration was higher in 25 and $50 \mu \mathrm{M}$ ALA groups than $100 \mu \mathrm{M}$ ALA groups $(p<0.05)$, however, it was not differ compared to control group. Both of 25 and $50 \mu \mathrm{M}$ ALA enhanced monospermic fertilization
(A)
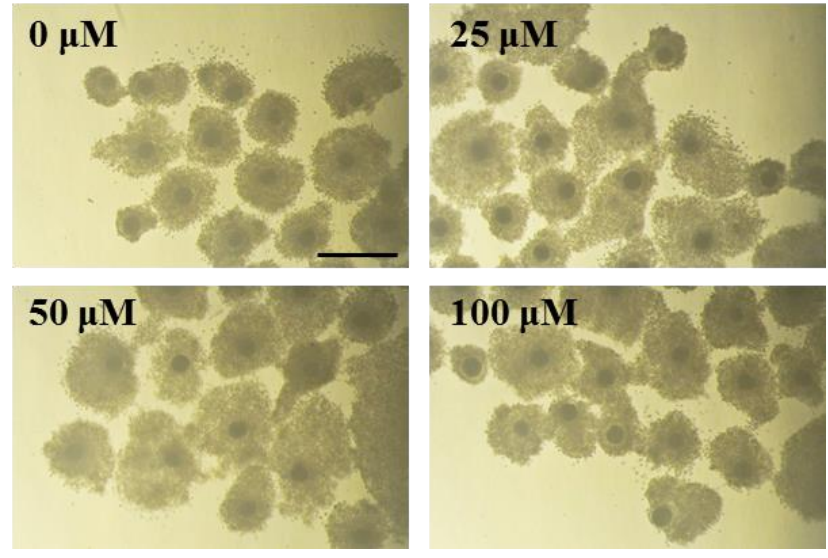

(B)

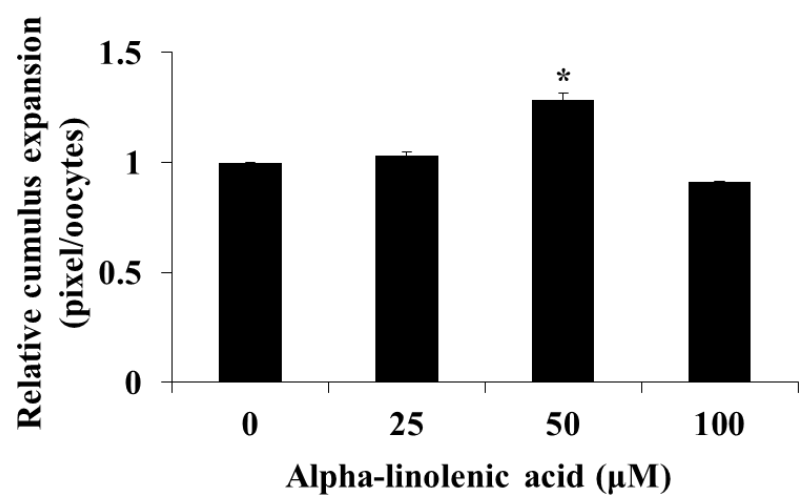

Fig. 1. Effect of alpha-linolenic acid during in vitro maturation on cumulus expansion of porcine oocytes at 22 hours after maturation. (A) Microscopic images of expanded cumulus layer, (B) Relative value of cumulus area normalized to control group. Asterisk indicates a significant difference $(p<0.05)$.

( $p<0.05)$. The IVF efficiency was increased in all of ALA treatment, however, there were no significant difference.

\section{Effect of ALA during IVM on developmental} competence of porcine oocytes

Embryonic developement at $48 \mathrm{~h}$ after IVF was increased by 25 and $50 \mu \mathrm{M}$ ALA treatment compared to control group (Table $3 ; p<0.05$ ), in particular, treatment of $50 \mu \mathrm{M}$ ALA promoted early embryo develop to 4 and 8 cells stages (Fig. $4 ; p<0.05$ ). Although both of 25 and $50 \mu \mathrm{M}$ 


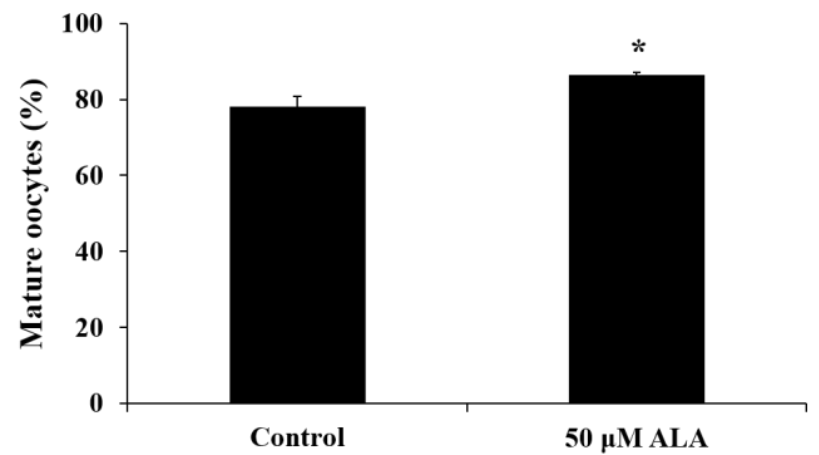

Fig. 2. Effect of alpha-linolenic acid (ALA) during in vitro maturation on nuclear maturation of porcine oocytes at 44 hours after maturation. Asterisk indicates a significant difference $(p<0.05)$.

ALA treatment enhanced early embryo development, blastocyst formation and number of cells in blastocysts did not differ in 25 and $50 \mu \mathrm{M}$ ALA groups compared to control group (Table 3).

\section{DISCUSSION}

Although IVP system of porcine embryos was improved by numerous reseaches, because of damage from in vitro environments, developmental competence of in vitro mature oocytes is still lower than in vivo mature oocytes (Guerin et al., 2001). Numerous reseaches have been tried to improve quality of IVM oocytes by supplementation of

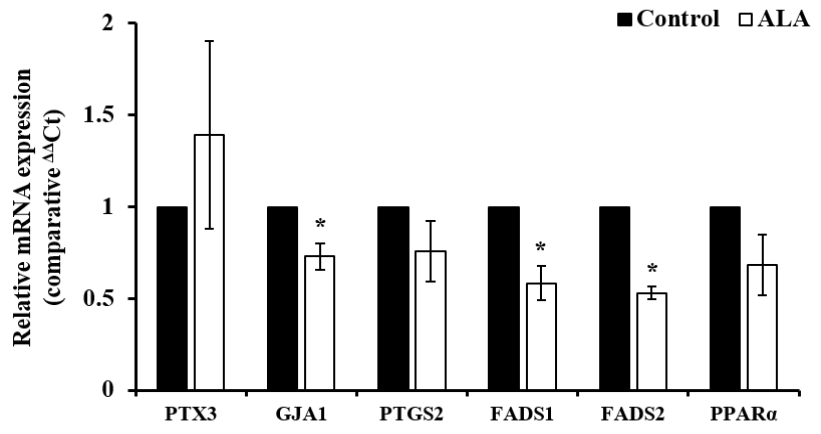

Fig. 3. Change of cumulus expansion-related (PTX3, pentraxin; GJA1, gap junction protein alpha 1; PTGS2, prostaglandin-endoperoxide synthase 2 and fatty acid metabolism-related (FADS1, delta-6 desaturase; FADS2, delta-5desaturase; PPARo, peroxisome proliferator-activated receptor-alpha) genes in cumulus cells by alpha-linolenic acid (ALA; $50 \mu \mathrm{M})$ during in vitro maturation. Asterisk indicates a significant difference $(p<0.05)$.

substances. FAs is one of energy source and it is contained in cytoplasm of porcine and bovine oocytes (McKeegan and Sturmey, 2011). Recently, many studies had reported that dietary supplement of PUFAs in cattle could enhanced reproductive performance (Wathes et al., 2007) and addition of oleic acid in maturation medium supported the development of oocyte via inhibition harmful effects of saturated FAs (Wang and Tsujii, 1999; Leroy et al., 2003; Aardema et al., 2011; Yenuganti et al., 2016; Fayezi et al.,

Table 2. Effects of alpha-linolenic acid (ALA) during in vitro maturation on sperm penetration and monospermic fertilization in porcine oocytes

\begin{tabular}{ccccc}
\hline \hline \multirow{2}{*}{$\begin{array}{c}\text { ALA } \\
(\mu \mathrm{M})\end{array}$} & \multirow{2}{*}{$\begin{array}{c}\text { No. of } \\
\text { examined oocytes }\end{array}$} & Penetration (\%) & \multicolumn{2}{c}{ IVF parameters } \\
\cline { 4 - 5 } 0 & 128 & $88.28 \pm 1.69^{\mathrm{ab}}$ & $42.97 \pm 2.33^{\mathrm{b}}$ & IVF efficiency $(\%)$ \\
25 & 131 & $92.37 \pm 3.18^{\mathrm{a}}$ & $53.44 \pm 3.71^{\mathrm{a}}$ & $58.67 \pm 0.95$ \\
50 & 120 & $93.33 \pm 0.86^{\mathrm{a}}$ & $52.50 \pm 3.00^{\mathrm{a}}$ & $56.85 \pm 2.68$ \\
100 & 116 & $83.62 \pm 1.54^{\mathrm{b}}$ & $47.41 \pm 2.19^{\mathrm{ab}}$ & $56.70 \pm 3.29$ \\
\hline
\end{tabular}

${ }^{\mathrm{a}, \mathrm{b}}$ Mean values with different superscripts are significantly difference $(p<0.05)$.

Monospermy, rate of monospermic zygotes to the number of total inseminated oocytes; IVF efficiency, rate of monospermic zygotes to the number of penetrated oocytes. 
Table 3. Effect of alpha-linolenic acid (ALA) during in vitro maturation on developmental competence of porcine oocytes

\begin{tabular}{ccccc}
\hline \hline \multirow{2}{*}{$\begin{array}{c}\text { ALA } \\
(\mu \mathrm{M})\end{array}$} & $\begin{array}{c}\text { No. of examined } \\
\text { oocytes in IVF }\end{array}$ & \multicolumn{2}{c}{ No. of embryo development (\%) } & $\begin{array}{c}\text { Number of cells } \\
\text { in blastocyst }\end{array}$ \\
\cline { 2 - 4 } & 193 & $72(37.4 \pm 0.3)^{\mathrm{c}}$ & $26(13.3 \pm 0.8)^{\mathrm{a}}$ & $57.43 \pm 5.3^{\mathrm{ab}}$ \\
25 & 201 & $85(43.3 \pm 0.7)^{\mathrm{b}}$ & $29(15.3 \pm 1.1)^{\mathrm{a}}$ & $66.57 \pm 1.7^{\mathrm{a}}$ \\
50 & 206 & $99(46.7 \pm 0.5)^{\mathrm{a}}$ & $31(15.5 \pm 1.3)^{\mathrm{a}}$ & $69.14 \pm 1.7^{\mathrm{a}}$ \\
100 & 206 & $82(41.1 \pm 0.7)^{\mathrm{bc}}$ & $20(9.8 \pm 1.0)^{\mathrm{b}}$ & $55.86 \pm 3.5^{\mathrm{b}}$ \\
\hline
\end{tabular}

${ }^{\mathrm{a}-\mathrm{c}}$ Mean values with different superscripts are significantly difference $(p<0.05)$.

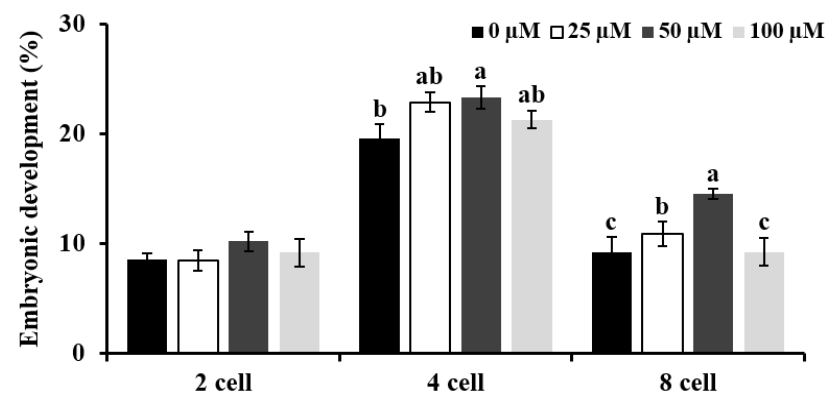

Fig. 4. Change of embryonic development stages by different concentration of alpha-linolenic acid $(0$ $25,50$, and $100 \mu \mathrm{M})$ during in vitro maturation in porcine oocytes. ${ }^{\mathrm{a}-\mathrm{c}}$ Different superscripts indicate significant difference $(p<0.05)$.

2018).

This study was conducted to confirm effect of ALA during IVM on change of fertilization capacity and developmental competence by promoting cumulus expansion. Our fidings showed that cumulus expansion and nuclear maturation were increased by treatment of $50 \mu \mathrm{M}$ ALA, whereas FAs metabolism- and cumulus expansion-related genes were down-regulated. Both of monospermic fertilization and early embryo development were also enhanced by $50 \mu \mathrm{M}$ ALA, however, blastocyst formation was not influenced.

Cumulus cells play a very important role in delivering a variety of factors to the oocyte via gap junction communication (Gilula et al., 1978; Coskun et al., 1994). These transport of substances including metabolites and low size molecules by gap junction is closely associated with oocytes maturation. In present study, cumulus expansion and nuclear maturation were significantly increased by $50 \mu \mathrm{M}$ ALA at $22 \mathrm{~h}$ and $44 \mathrm{~h}$ after maturation, respectively. Interaction between oocytes and cumulus cells was mediated by gap junction and it induced both of cumulus expansion and oocyte maturation. Especially, cysteine and glutamine that were transported by gap junction from cumulus cells into oocytes were synthesized to GSH in oocytes and synthesis of GSH is important indicator of cytoplasmic maturation (Mori et al., 2000). Lee et al. (2016a) reported that supplementation of ALA increased intracellular GSH level in porcine oocytes after IVM. Based on these research, we hypothesize that treatment of ALA promotes cumulus expansion and oocyte maturation via activation of gap junction at $22 \mathrm{~h}$ after maturation. Therefore, GSH synthesis in oocytes during maturation will be measured in further study.

FAs of metabolism and $\beta$-oxidation are closely associated with energy production, prostaglandins synthesis, imflammatory response, and other cellular processes (Foyer et al., 2003). As a precursor, ALA is synthesized to eicosapentaenoic acid (EPA) and docosahexaenoic acid (DHA) by FADS1, FADS2, and PPAR $\alpha$. In particular, PPAR $\alpha$ regulates lipid metabolism, FAs transport, FAs binding and activation, and mitochondrial FAs $\beta$-oxidation, thereby 
it promotes the absorption, utilization and catabolism of FAs (Dunning et al., 2014; Lee et al., 2016b). We expected that addition of ALA during maturation period could induce expression of FAs metabolism-related genes. However, the expression of FADS1 and FADS2 mRNA was significantly reduced by $50 \mu \mathrm{M}$ ALA treatment and PPAR $\alpha$ mRNA was slightly decreased in ALA-treated cumulus cells at $44 \mathrm{~h}$ after maturation. Energy balance during maturation is crucial to nuclear and cytoplasmic maturation, and subsequent development in oocytes. However, excessive amount of FAs may be caused lipid peroxidation that is one of cause of reduced embryo quality (Lequarré et al., 2001; Reis et al., 2003). Therefore, we hypothesize that decreasing of FAs metabolism-related genes in ALAtreated cumulus cells could prevent excessive energy production and lipid peroxidation by ALA treatment. To investigate our hypothesis, expression of FAs metabolismrelated genes, oxidative stress status, and lipid peroxidation according to culture time during maturation will be measured in further study.

Cumulus expansion of COCs is one of crucial parameter for evaluation of oocyte maturation and it is closely involved in function of gap junction. Various nutrients, metabolites, and substrates are transported through gap junction between cumulus cells and oocytes for sucessful maturation (Li et al., 2015). And several genes including PTX3, GJA1, and PTGS2 are involved with cumulus expansion and function of gap junction in mammalian oocytes (Zhang et al., 2005; Jia et al., 2014; Li et al., 2015). In present study, although treatment of $50 \mu \mathrm{M}$ ALA enhanced cumulus expansion at $22 \mathrm{~h}$ after maturation, GJAl mRNA in cumulus cells was downregulated at $44 \mathrm{~h}$ after maturation. And PTGS2 mRNA was slightly decreased, however, there were not significant difference. Reduction of GJAI mRNA by ALA was similar with results of FA metabolism-related genes. Jia et al. (2014) reported that trans10, cis-12 conjugated linoleic acid (t19c12 CLA) promoted protein expression of cyclo-oxygenase 2 (COX2; also known as PTGS2) in porcine oocytes for $22 \mathrm{~h}$ after maturation, whereas it was not differed at $44 \mathrm{~h}$. These findings lead to predict that ALA treatment during first $22 \mathrm{~h}$ of maturation would promote FAs metabolism and gap junction for transport and production of energy, however, these are supressed to maintain energy balance during $22 \mathrm{~h}$ after first maturarion period. Therefore, our futher plan include invastigation of cumulus expansion-related genes and cAMP levels during first $22 \mathrm{~h}$ in IVM.

Formation of the zygote and embryo development after fertilization are considered as marker of the developmental ability in oocytes (Fayezi et al., 2018). During the maturation of the oocyte, incomplete cytoplasmic maturation results in polyspermy and lower development of embryos in vitro (Wang et al., 1997). In present study, monospermic fertilization and early embryonic development (developed to 4 and 8 cell) were increased by treatment of 25 and 50 $\mu \mathrm{M}$ ALA during IVM. As a marker of cellular maturation, GSH is increased in oocytes during maturation (DeMatos et al., 2000) and is involved with male pronuclei formation in oocytes (Mori et al., 2000). In our previous study, reduced GSH level in oocytes by $\mathrm{H}_{2} \mathrm{O}_{2}$ was recovered in $50 \mu \mathrm{M}$ ALA and it suggested that ALA treatment could promote GSH synthesis in oocytes (Lee et al., 2017b). Furthermore, FAs are regarded as potential metabolic substrates in oocytes and early-stage embryos and are required as an energy source for the metabolism of embryos in pre-implantation of cows and pigs (Sturmey et al., 2009). Therefore, we expected that the addition of ALA could improve fertilization parameters and early development by increasing of GSH synthesis and energy production during maturation.

In conclusion, our findings show that $50 \mu \mathrm{M}$ ALA during maturation enhanced cumulus expansion, nuclear maturation, monospermic fertilization, and early embryonic development, however, quality and formation of blastocyst were not influenced. Interestingly, FA metabolismand cumulus expansion-related genes were reduced by 
ALA at $44 \mathrm{~h}$ after maturation. These results suggest that benefical effect and metabolism of ALA are occured during first $22 \mathrm{~h}$ of maturation and it might be closely assodicated with cytoplasmic maturation and gap junctional communication between oocytes and cumulus cells. Therefore, investigation of FA metabolism and energy production in oocytes during early maturation stage is needed.

\section{ACKNOWLEDGEMENTS}

This study is supported by 2015 Research Grant from Kangwon National University (No. 520160166).

\section{REFERENCES}

Aardema H, Vos PLAM, Lolicato F, Roelen BAJ, Knijn HM, Vaandrager AB, Helms JB, Gadella BM (2011) Oleic acid prevents detrimental effects of saturated fatty acids on bovine oocyte developmental competence. Biol Reprod 85:62-69.

Childs S, Hennessy AA, Sreenan JM, Wathes DC, Cheng Z, Stanton C, Kenny DA (2008) Effect of level of dietary n-3 polyunsaturated fatty acid supplementation on systemic and tissue fatty acid concentrations and on selected reproductive variables in cattle. Theriogenology 70:595-611.

Coskun S, Lin YC (1994) Effects of transforming growth factors and activin-A on in vitro porcine oocyte maturation. Mol Reprod Dev 38:153-159.

De Matos DG, Furnus CC (2000) The importance of having high glutathione (GSH) level after bovine in vitro maturation on embryo development: Effect of $\beta$-mercaptoethanol, cysteine and cystine. Theriogenology 53: 761-771.

Dunning KR, Anastasi MR, Zhang VJ, Russell DL, Robker RL (2014) Regulation of fatty acid oxidation in mouse cumulus-oocyte complexes during maturation and modulation by PPAR agonists. PLOS ONE 9:e87327.
Elahi F, Lee H, Lee Y, Park B, Lee J, Hyun SH, Lee E (2016) Cilostazol improves developmental competence of pig oocytes by increasing intraoocyte cyclic adenosine monophosphate level and delaying meiotic resumption. Reprod Domest Anim 51:220-226.

Fayezi S, Leroy JLMR, Novin MG, Darabi M (2018) Oleic acid in the modulation of oocyte and preimplantation embryo development. Zygote 26:1-13.

Foyer CH, Noctor G (2003) Redox sensing and signalling associated with reactive oxygen in chloroplasts, peroxisomes and mitochondria. Physiol Plant 119:355-364.

Fouladi-Nashta AA, Gutierrez CG, Gong JG, Garnsworthy PC, Webb R (2007) Impact of dietary fatty acids on oocyte quality and development in lactating dairy cows. Biol Reprod 77:9-17.

Gilchrist RB (2010) Recent insights into oocyte-follicle cell interactions provide opportunities for the development of new approaches to in vitro maturation. Reprod Fertil Dev 23:23-31.

Gilula NB, Epstein ML, Beers WH (1978) Cell-to-cell communication and ovulation. A study of the cumulusoocyte complex. J Cell Biol 78:58-75.

Guerin P, El Mouatassim S, Menezo Y (2001) Oxidative stress and protection against reactive oxygen species in the pre-implantation embryo and its surroundings. Hum Reprod Update 7:175-189.

Homa ST, Brown CA (1992) Changes in linoleic acid during follicular development and inhibition of spontaneous breakdown of germinal vesicles in cumulus-free bovine oocytes. J Reprod Fertil 94:153-160.

Hoodbhoy T, Talbot P (1994) Mammalian cortical granules: Contents, fate and function. Mol Reprod Dev 39: 439-448.

Jia B, Wu G, Fu X, Mo X, Du M, Hou Y, Zhu S (2014) trans-10, cis-12 conjugated linoleic acid enhances in vitro maturation of porcine oocytes. Mol Reprod Dev 81:20-30.

Kwak SS, Cheong SA, Jeon Y, Lee E, Choi KC, Jeung EB, 
Hyun SH (2012) The effects of resveratrol on porcine oocyte in vitro maturation and subsequent embryonic development after parthenogenetic activation and in vitro fertilization. Theriogenology 78:86-101.

Lee JE, Yong H, Kim HY, Lee WH, Cheong HT, Yang BK, Park CK (2017a) Effect of alpha-linolenic acid on oocyte maturation and embryo development in pigs. Dev Reprod 21:205-213.

Lee JE, Hwangbo Y, Kim HY, Cheong HT, Yang BK, Park CK (2017b) Antioxidant effect of alpha-linolenic acid during in vitro maturation in porcine oocytes. Reprod Dev Biol 41:65-70.

Lee Y, Lee H, Park B, Elahi F, Lee J, Lee ST, Park CK, Hyun H, Lee E (2016a) Alpha-linolenic acid treatment during oocyte maturation enhances embryonic development by influencing mitogen-activated protein kinase activity and intraoocyte glutathione content in pigs. J Anim Sci 94:3255-3263.

Lee S, Jin JX, Khoirinaya C, Kim GA, Lee BC (2016b) Lanosterol influences cytoplasmic maturation of pig oocytes in vitro and improves preimplantation development of cloned embryos. Theriogenology 85:575-584.

Lequarre AS, Feugang JM, Malhomme O, Donnay I, Massip A, Dessy F, Van Langendonckt A (2001) Expression of $\mathrm{Cu} / \mathrm{Zn}$ and $\mathrm{Mn}$ superoxide dismutases during bovine embryo development: Influence of in vitro culture. Mol Reprod Dev 58:45-53.

Leroy J, Vanholder T, Van Soom A, Opsomer G, Bols P, de Kruif A (2005) Effect of oleic acid during in vitro maturation and fertilisation, first cleavage and embryo development of bovine cumulus-oocyte complexes. Reprod Domest Anim 38:328.

Li SH, Lin MH, Hwu YM, Lu CH, Yeh LY, Chen YJ, Lee RKK (2015) Correlation of cumulus gene expression of GJA1, PRSS35, PTX3, and SERPINE2 with oocyte maturation, fertilization, and embryo development. Reprod Biol Endocrinol 13:93.

Li Y, Zhang Z, He C, Zhu K, Xu Z, Ma T, Tao J, Liu G
(2015) Melatonin protects porcine oocyte in vitro maturation from heat stress. J Pineal Res 59:365-375.

Li YH, Ma W, Li M, Hou Y, Jiao LH, Wang WH (2003) Reduced polyspermic penetration in porcine oocytes inseminated in a new in vitro fertilization (IVF) system: Straw IVF. Biol Reprod 69:1580-1585.

Marei WF, Wathes DC, Fouladi-Nashta AA (2009) The effect of linolenic acid on bovine oocyte maturation and development. Biol Reprod 81:1064-1072.

McKeegan PJ, Sturmey RG (2011) The role of fatty acids in oocyte and early embryo development. Reprod Fertil Dev 24:59-67.

Mori T, Amano T, Shimizu H (2000) Roles of gap junctional communication of cumulus cells in cytoplasmic maturation of porcine oocytes cultured in vitro. Biol Reprod 62:913-919.

Reis A, Rooke JA, McCallum GJ, Staines ME, Ewen M, Lomax MA, McEvoy TG (2003) Consequences of exposure to serum, with or without vitamin E supplementation, in terms of the fatty acid content and viability of bovine blastocysts produced in vitro. Reprod Fertil Dev 15:275-284.

Sovernigo TC, Adona PR, Monzani PS, Guemra S, Barros FDA, Lopes FG, Leal CLV (2017) Effects of supplementation of medium with different antioxidants during in vitro maturation of bovine oocytes on subsequent embryo production. Reprod Domest Anim 52:561-569.

Sturmey RG, Reis A, Leese HJ, McEvoy TG (2009) Role of fatty acids in energy provision during oocyte maturation and early embryo development. Reprod Domest Anim 44:50-58.

Tareq KMA, Akter QS, Khandoker MAMY, Tsujii H (2012) Selenium and vitamin E improve the in vitro maturation, fertilization and culture to blastocyst of porcine oocytes. J Reprod Dev 58:621-628.

Wang G, Tsujii H (1999) Metabolism of exogenous palmitic and oleic acids by preimplantation mouse embryos. J Mamm Ova Res 16:10-15. 
Wang WH, Abeydeera LR, Cantley TC, Day BN (1997)

Effects of oocyte maturation media on development of pig embryos produced by in vitro fertilization. J Reprod Fertil 111:101-108.

Wathes DC, Abayasekara DRE, Aitken RJ (2007) Polyunsaturated fatty acids in male and female reproduction. Biol Reprod 77:190-201.

Yenuganti VR, Viergutz T, Vanselow J (2016) Oleic acid induces specific alterations in the morphology, gene expression and steroid hormone production of cultured bovine granulosa cells. Gen Com Endocrinol 232:134144.

Zhang X, Jafari N, Barnes RB, Confino E, Milad M, Kazer RR. (2005) Studies of gene expression in human cumulus cells indicate pentraxin 3 as a possible marker for oocyte quality. Fertil Steril 83:1169-1179. 